\title{
PENGELOLAAN WILAYAH DAN SUMBER DAYA PESISIR TERINTEGRASI DALAM IMPLEMENTASI RENCANA TATA RUANG KAWASAN INDUSTRI OLEOCHEMICAL MALOY KUTAI TIMUR; (SEBUAH TELAAH KRITIS)
}

\author{
Isal Wardhana \\ Program Magister Ilmu Lingkungan, Universitas Mulawarman \\ email:pilanjau@gmail.com
}

Paper Accepted: 24 Maret 2020 Paper Reviewed: 25-31 Maret 2020

Paper Edited: 01-15 April 2020 Paper Approved: 25 April 2020

\begin{abstract}
ABSTRAK
Pengalaman membuktikan bahwa aktivitas pesisir sangat potensial dalam membangkitkan sektor riil, hal ini terbukti saat terjadiknya krisis ekonomi, kegiatan pada wilayah pesisir laut justru mendapatkan keuntungan yang berlipat ganda. Oleh sebab itu penting untuk mengembangkan kawasan pesisir dan mengelola sumber daya pesisir yang terintegrasi bersandarkan pada pembangunan berkelanjutan (sustainable development) dan keberlanjutan kehidupan sosial (sustainable society). Fokus penelitian ini adalah menggambarkan pengelolaan wilayah dan sumber daya pesisir terintegrasi dalam implementasi tata ruang (RTR) Kawasan Industri Oleochemical (KIO) Maloy di Kutai Timur sebagai telaah kritis studi kasus. Metode penelitian ini menggunakan pendekatan kualitatif, dengan teknik pengumpulan data melalui observasi. Observasi adalah dasar semua ilmu pengetahuan. Para ilmuwan hanya dapat bekerja berdasarkan data, yaitu fakta mengenai dunia kenyataan yang diperoleh melalui observasi (Sugiyono, 2012). Peneliti juga melakukan studi literatur/dokumen. Dokumen adalah peristiwa yang sudah berlalu. Dokumen bisa berupa/berbentuk tulisan, gambar atau karya-karya dari seseorang (Sugiyono, 2012). Data-data yang diperoleh kemudian diolah, disajikan dan selanjutnya menarik kesimpulan. Analisis data ini disebut sebagai mengolah dan menafsirkan data (Muhajir, 1996). Dengan data itu, peneliti kemudian mengeksplorasi dan atau memotret situasi secara menyeluruh dan mendalam (Sugiyono, 2012). Keberadaan hutan mangrove primer terancam oleh perluasan dan pengembangan zona industri. Sementara pada RTR tersebut hanya menyisakan sedikit zona perlindungan setempat dan zona ekosistem mangrove. Zona pelayaran umum dalam pola pemanfaatan ruang juga terdapat pada wilayah pesisir (teluk) bersandingan dengan zona Ruang Terbuka Hijau (RTH) dan jalan dalam kawasan inti. Pada zona ini yang mengkhawatirkan adalah tingginya sedimentasi pada wilayah perairan teluk dimana akan berdampak pada pendangkalan dan susahnya kapal-kapal besar akan bersandar, serta tingginya tingkat abrasi di beberapa tempat sepanjang pinggiran pantai.
\end{abstract}

Kata Kunci: Sumberdaya pesisir, KIO Maloy, Kutai Timur

\section{PENDAHULUAN}

Kebijakan Hukum di Indonesia dalam hal pengelolaan wilayah pesisir di atur dalam Undang-Undang (UU) No. 27 Tahun 2007 tentang Pengelolaan Wilayah Pesisir dan Pulau-
Pulau Kecil yang telah diubah menjadi UU No. 1 Tahun 2014 tentang Perubahan Atas UU No. 27 Tahun 2007 Tentang Pengelolaan Wilayah Pesisir dan Pulau-Pulau Kecil. Hal ini tentu saja berkonsekuensi logis menjadi rujukan (pedoman) dasar terhadap segala proses 
pembangunan dan pengembangan kawasan pesisir di Indonesia. Adapun peraturan perundangan sektoral lainnya yang masuk dalam domain pengelolaan wilayah pesisir menjadi peraturan perundangan ikutan yang tidak dapat terpisahkan.

UU tentang Pengelolaan Wilayah Pesisir dan Pulau-Pulau Kecil mendefinisikan bahwa yang dimaksud dengan Pengelolaan Wilayah Pesisir dan Pulau-Pulau Kecil adalah suatu pengkoordinasian perencanaan, pemanfaatan, pengawasan, dan pengendalian sumber daya pesisir dan pulau-pulau kecil yang dilakukan oleh Pemerintah dan Pemerintah Daerah, antarsektor, antara ekosistem darat dan laut, serta antara ilmu pengetahuan dan manajemen untuk meningkatkan kesejahteraan rakyat.

Sedangkan Sumber Daya Pesisir dan Pulau-Pulau Kecil adalah sumber daya hayati, sumber daya non hayati; sumber daya buatan, dan jasa lingkungan; sumber daya hayati meliputi ikan, terumbu karang, padang lamun, mangrove dan biota laut lain; sumber daya non hayati meliputi pasir, air laut, mineral dasar laut; sumber daya buatan meliputi infrastruktur laut yang terkait dengan kelautan dan perikanan, dan jasa lingkungan berupa keindahan alam, permukaan dasar laut tempat instalasi bawah air yang terkait dengan kelautan dan perikanan serta energi gelombang laut yang terdapat di wilayah pesisir.

Adapun pendapat lain yang dimaksud dengan Pengelolaan Pesisir Terpadu adalah sebuah proses dinamis dan berkelanjutan yang menyatukan pemerintah dan masyarakat, ilmu pengetahuan dan pengelolaan, serta kepentingan sektoral dan masyarakat umum dalam menyiapkan dan melaksanakan suatu rencana terpadu untuk perlindungan dan pengembangan sumberdaya dan ekosistem pesisir (GESAMP, 1996).

Indonesia merupakan negara kepulauan yang memiliki keanekaragaman hayati tinggi dan memiliki jangkauan wilayah daratan dan pesisir luas yang dapat dimanfaatkan untuk kesejahteraan masyarakat dan pengembangan kawasan pada wilayah pesisir. Dan tidak dapat dipungkiri masyarakat yang berada di wilayah pesisir masih ada yang hidup pada garis kemiskinan, release dari Badan Pusat Statistik (BPS) pada tahun 2018 mengatakan setidaknya 20 persen sampai dengan 80 persen nelayan dan 10 persen sampai 30 persen pembudidaya tergolong miskin. Selain masalah sosial dan ekonomi, kawasan pesisir juga memiliki sejumlah persoalaan lingkungan, ekologi dan belum proporsionalnya alokasi ruang atau zona pesisir untuk kepentingan-kepentingan tersebut.
Pengalaman membuktikan bahwa aktivitas pesisir sangat potensial dalam membangkitkan sektor riil, hal ini terbukti saat terjadiknya krisis ekonomi, kegiatan pada wilayah pesisir laut justru mendapatkan keuntungan yang berlipat ganda. Oleh sebab itu penting untuk mengembangkan kawasan pesisir dan mengelola sumber daya pesisir yang terintegrasi bersandarkan pada pembangunan berkelanjutan (sustainable development) dan keberlanjutan kehidupan sosial (sustainable society).

Fokus penelitian ini adalah menggambarkan pengelolaan wilayah dan sumber daya pesisir terintegrasi dalam implementasi tata ruang (RTR) Kawasan Industri Oleochemical (KIO) Maloy di Kutai Timur sebagai telaah kritis studi kasus.

\section{METODE PENELITIAN}

\begin{abstract}
Metode penelitian ini menggunakan pendekatan kualitatif, dengan teknik pengumpulan data melalui observasi. Observasi adalah dasar semua ilmu pengetahuan. Para ilmuwan hanya dapat bekerja berdasarkan data, yaitu fakta mengenai dunia kenyataan yang diperoleh melalui observasi (Sugiyono, 2012).

Peneliti juga melakukan studi literatur/dokumen. Dokumen adalah peristiwa yang sudah berlalu. Dokumen bisa berupa/berbentuk tulisan, gambar atau karyakarya dari seseorang (Sugiyono, 2012).

Data-data yang diperoleh kemudian diolah, disajikan dan selanjutnya menarik kesimpulan. Analisis data ini disebut sebagai mengolah dan menafsirkan data (Muhajir, 1996). Dengan data itu, peneliti kemudian mengeksplorasi dan atau memotret situasi secara menyeluruh dan mendalam (Sugiyono, 2012).
\end{abstract}

\section{HASIL DAN PEMBAHASAN}

\section{Konsep Dasar Pengelolaan Wilayah Pesisir}

Dasar konseptual pengembangan wilayah pesisir di Indonesia bersandar pada Pengelolaan Wilayah Pesisir Terpadu (PWPT), diistilahkan dengan Integrated Coastal Zone Management (ICZM) yang pertama kali dikemukakan pada Konferensi Pesisir Dunia (World Conference of Coast) pada tahun 1993. Konsep ini kemudian diadopsi oleh Pemerintah Indonesia dan dituangkan dalam UU No. 27 Tahun 2007 tentang Pengelolaan Wilayah Pesisir dan PulauPulau Kecil yang telah diubah dengan UU No. 1 Tahun 2014 tentang Perubahan Atas UndangUndang No. 27 Tahun 2007 Tentang 
Pengelolaan Wilayah Pesisir dan Pulau-Pulau Kecil.

Pandangan peneliti yang menjadi perbedaaan ketika konsepsi dasar ICZM tersebut dituangkan dalam bentuk regulasi; Pemerintah Indonesia memasukkan dan mengakui aspek-aspek pengelolaan yang sudah dilakukan oleh masyarakat adat dan/atau masyarakat lokal yang sudah sejak lama dipraktikkan dengan nilai-nilai luhur. Konsep lokal ini diistilahkan dengan kearifan tradisional (traditional wisdom), walaupun terdapat rentang waktu yang panjang dalam memasukkan instrumen kearifan tradisional tersebut.

Dahuri, et al, (2001) mengatakan bahwa pendekatan pengelolaan pesisir melibatkan dua atau lebih ekosistem, sumber daya, dan kegiatan pemanfaatan (pembangunan) secara terpadu guna mencapai pembangunan wilayah pesisir secara berkelanjutan. Untuk mewujudkan hal tersebut maka keterpaduan perencanaan dan pengelolaan kawasan pesisir dan laut mencakup beberapa aspek, di antaranya adalah: keterpaduan ekologi, keterpaduan sektoral, keterpaduan kebijakan vertikal, kerpaduan disiplin ilmu dan keterpaduan stakeholders.

\section{Konektifitas Komponen dalam Pengelolaan Wilayah Pesisir}

Wilayah pesisir merupakan daerah yang strategis, tetapi juga memiliki kerentanan terhadap gangguan dan perubahan ekosistem dan lingkungan hidup, kerentanan bisa diakibatkan oleh faktor alam, aktivitas manusia ataupun kombinasi dari keduanya. Fakta menunjukkan bahwa aktivitas manusia mendominasi menjadi penyebab terdegradasinya wilayah pesisir dan berdampak pada kerusakan ekosistem dan lingkungan hidup seperti; pengurangan kawasan mangrove, erosi pantai, pencemaran air akibat limbah domestik dan industri, rusaknya terumbu karang dan tingginya tingkat sedimentasi.

Daerah Aliran Sungai (DAS) merupakan kawasan yang menghubungkan daratan di hulu dengan kawasan/wilayah pesisir. Sehingga keberadaan DAS menjadi komponen sangat penting dan mempengaruhi kawasan pesisir. Pendekatan pengelolaan berbasiskan ekosistem DAS diyakini akan lebih baik dibandingkan berpendekatan batas wilayah administrative, lebih dapat mengintegrasikan kepentingan semua pihak dalam mengelola kawasan pesisir, termasuk dalam hal mengintervensi kebijakan.

Penerapan tata guna lahan dan pengelolaan DAS yang tidak berwawasan lingkungan dapat menimbulkan erosi dan sedimentasi, erosi mempengaruhi produktifitas lahan yang biasanya mendominasi pada bagian hulu dan dapat memberikan dampak negatif berupa terkumpulnya endapan/sedimentasi pada DAS bagian hilir (muara sungai), yang juga berakibat pada pendangkalan wilayah pesisir dan perairan. Pada sisi lain, pencemaran air yang diakibatkan oleh limbah domestik dan industri juga menjadi persoalaan tersendiri, limbah-limbah tersebut dapat dibawa oleh aliran DAS menuju wilayah pesisir laut.

Beberapa factor yang mempengaruhi dan menjadi ancaman penurunan kualitas DAS diantaranya adalah; hilangnya vegetasi akibat pembukaan lahan dan penebangan baik untuk lahan pertanian, pertambangan, perkebunan skala besar, pertambakan serta pemukiman. Selanjutnya pembangunan infrastruktur, terutama yang dapat meningkatkan limpasan air. Kemudian pembuangan limbah industri dan domestik rumah tangga ke DAS atau sub DAS yang tidak diolah terlebih dulu.

Mengingat pentingnya fungsi DAS dan sub DAS, maka sangat penting menjaga kelestarian dan merehabilitasinya dengan cara menanggulangi lahan kritis, rehabilitasi lahan, revegetasi, konservasi tanah, menjaga kawasan hutan, dan mengevaluasi pembukaan kawasan/lahan untuk perizinan pembangunan infrastruktur dan industri ekstraktif, serta mengawasi pencemaran limbah industri dan domestik.

Ekosistem mangrove merupakan habitat kehidupan beragam jenis ikan, kepiting, udang, kerang, reptil, dan mamalia. Detritus dari mangrove adalah dasar pembentukan rantai makanan bagi banyak organisme pesisir laut. Hutan mangrove dengan akar yang kokoh mampu untuk menahan hempasan ombak dan mencegah abrasi pantai, selain berfungsi untuk perangkap sedimen dan menetralisir sebagian senyawa-senyawa yang bersifat racun (toxin).

Kayu mangrove biasanya dimanfaatkan oleh masyarakat setempat sebagai kayu bakar, bahan bangunan, dan membuat arang, serta beberapa jenis tanaman mangrove berfungsi sebagai obat luka akibat tersengat ikan. Masyarakat biasanya juga memanfaatkan kawasan hutan mangrove ini untuk menangkap ikan, kepiting, udang dan bahan makanan lainnya.

Ancaman kerusakan dan degradasi hutan mangrove biasanya disebabkan oleh pembukaan kawasan hutan mangrove untuk pertambakan skala besar, pengembangan pemukiman, pengembangan kawasan industri, terminal dan 
pelabuhan, serta pencemaran limbah yang mengancam kelestarian hutan mangrove.

Upaya yang dilakukan dalam memperbaiki kawasan hutan mangrove biasanya dengan melakukan penanaman kembali bibit mangrove pada hutan mangrove yang terdegradasi, mengimplementasikan tambak yang ramah lingkungan, perlindungan kawasan hutan mangrove yang masih terjaga, dan menghentikan semua aktivitas yang berpotensi merusak hutan mangrove, serta memanfaatkan keberadaan hutan mangrove dengan mengembangkan pola pemanfaatan mangrove berbasiskan masyarakat dan keberlanjutan.

\section{Pencemaran Lingkungan Hidup di Wilayah Perairan}

Dalam hubungannya dengan wilayah pesisir, pencemaran yang mendominasi adalah pencemaran perairan dan merupakan masalah yang sangat serius dimana tingginya tingkat pencemaran dapat menyebabkan terganggunya kesehatan manusia, dan mempengaruhi kegiatan perikanan. Bahan pencemar (polutan) biasanya bersumber dari kegiatan rumah tangga, industri, pembukaan lahan perkebunan dan pertanian skala besar, pertambangan, dan aktivitas transportasi laut.

Limbah rumah tangga, pertanian dan perkebunan dari bahan organik dan non organik akan meningkatkan eutrofikasi yang kemudian menambah jumlah populasi plankton tertentu yang pada saat-saat tertentu plankton tersebut akan mati, dan menambah konsumsi oksigen dalam jumlah besar sehingga oksigen terlarut menjadi berkurang, akibat yang ditimbulkan adalah kematian ikan dan organisme perairan lainnya.

Limbah rumah tangga yang mengandung mikroorganisme pathogen, limbah Bahan Beracun Berbahaya (B3) dan bahan pencemar lainnya dapat masuk ke dalam badan air, pencemaran logam berat dan limbah B3 ini dapat mempengaruhi sistem rantai makanan perairan. Minyak dan limbah B3 pada kadar tertentu juga dapat mengakibatkan pencemaran yang dapat merusak dan mematikan mangrove, padang lamun dan karang. Minyak biasanya berasal dari depo-depo bahan bakar dan transportasi perairan yang menghasilkan tumpahan-tumpahan minyak. Salah satu sumber pencemar air yang perlu diwaspadai adalah spesies eksotis yang terbawa dalam air pemberat kapal (ballast water). Biasanya air ini mengandung bermacam organisme kecil yang terambil dari pelabuhan persinggahan.
Pengalaman membuktikan, untuk mengembalikan kondisi perairan yang tercemar memerlukan waktu yang lama dan biaya yang besar, oleh sebab itu pencegahan pencemaran wilayah pesisir sangat penting dilakukan guna melindungi ekosistem pesisir. Diperlukan pengawasan yang ketat dan penegakan hukum lingkungan terhadap pelaku atau pihak-pihak yang melakukan pencemaran pada wilayah perairan.

\section{Pengembangan Pariwisata Pesisir}

Tidak dapat dipungkiri bahwa sektor pariwisata memberikan kontrinbusi secara langsung kepada masyarakat yang berdiam di wilayah pesisir, selain memberikan masukan Pendapatan Asli Daerah (PAD). Pengembangan sektor pariwisata idealnya sebagai salah satu sekor usaha yang ramah lingkungan, memberikan banyak manfaat ekonomi dan sosial. Tetapi jika tidak direncakan dan dikelola dengan benar maka pariwisata dapat memberikan dampak negatif.

Sejak dicetuskannya era Millenium Development Goal's (MDG's) pada tahun 2000, gagasan pariwisata terus berkembang ke arah pengembangan konsep ekologi wisata yang dikenal dengan ekowisata dan "Ecologi Village" yang dikenal dengan Ecovillage. Ekowisata dan Ecovillage dikemas dan bersifat natural dengan mengandalkan etalase keanekaragaman hayati tinggi, keunikan bentang alam, dan praktik kearifan tradisional masyarakat dalam mengelola sumber daya alam.

Gugusan landscape dan livescape dari wilayah daratan dan pesisir serta pulau-pulau kecil menjadi objek pariwisata yang sangat potensial untuk dikembangkan, mulai dari kawasan hutan hujan tropis dataran tinggi (tropical rain forest), hutan mangrove, hutan rawa, gugusan pantai, sampai dengan keanekaragaman hayati pada wilayah pesisir, pulau-pulau kecil dan laut.

Sektor pariwisata yang berbasis ekologi dan nilai-nilai sosial dalam masyarakat sebagai objek tentu saja harus berkorelasi positif dengan terjaganya kondisi ekologi, lingkungan hidup dan menjaga pranata-pranata sosial yang bersifat kelokalan. Pengembangan infrastruktur dan suprastruktur pariwisata hendaknya memperhitungkan sekecil mungkin dampak kerusakan ekologi dan lingkungan hidup. Pengelolaan limbah-limbah akibat tingginya jumlah kunjungan pariwisata harus dikelola dengan baik, begitu juga kawasan-kawasan potensial yang akan menjadi calon destinasi dan 
destinasi existing pariwisata pesisir dan pulaupulau kecil, haruslah dijaga dari kerusakan dan eksploitasi sumber daya alam yang mengancam ekologi dan lingkungan hidup.

Para pihak pemangku kepentingan sektor pariwisata saat ini sudah mulai meberikan perhatian terhadap pengembangan dan pengimplementasian ekowisata dan ecovillage dengan membangun industri pariwisata yang berbasiskan pemberdayaan masyarakat, prinsip konservasi sumber daya alam, pendidikan, rekreasi dan peningkatan ekonomi.

Dengan mengambil contoh kasus di Provinsi Kalimantan Timur, menurut hemat kami ada beberapa hal yang menjadi kendala dan tantangan dalam pengembangan sektor pariwisata di wilayah pesisir, di antaranya adalah: Pertama, belum maksimalnya dukungan kebijakan proteksi terhadap potensi keanekaragaman hayati dan sumber daya alam potensial yang menjadi calon destinasi baru pariwisata. Kedua, masih minimnya program dan penganggaran pada sektor industri pariwisata berbasis ekowisata dan ecovillage. Ketiga, masih adanya izin-izin eksploitasi sumber daya alam seperti izin pertambangan, perkebunan skala besar dan pengembangan kawasan industry ekstraktif pada Kawasan yang memiliki keanekaragaman hayati tinggi. Keempat, aksebilitas destinasi pariwisata yang sulit berdampak pada tingginya biaya wisatawan yang akan berkunjung. Kelima masih terbatasnya kemampuan masyarakat lokal dalam mengelola kawasan pariwisata, baik secara kelembagaan dan keanekaragaman hayatinya.

\section{Reklamasi}

Menurut UU No. 27 Tahun 2007 Tentang Pengelolaan Wilayah Pesisir dan Pulau-Pulau Kecil, reklamasi adalah kegiatan yang dilakukan oleh orang dalam rangka meningkatkan manfaat sumber daya lahan ditinjau dari sudut lingkungan dan sosial ekonomi dengan cara pengurukan, pengeringan lahan atau drainase. Dari definisi tersebut, dapat ditarik pengertian sederhana bahwa reklamasi memiliki tujuan utama menjadikan kawasan berair yang rusak menjadi kawasan yang lebih bermanfaat.

Reklamasi pantai dan laut menjadi "trending" pada kawasan perkotaan yang terletak di wilayah pesisir yang kemudian dimanfaatkan untuk keperluan ekonomi dan tujuan kawasan strategis. Biasanya digunakan sebagai lahan pemukiman, pengembangan kawasan industri, properti (bisnis dan pertokoan), pelabuhan udara, jalur transportasi, area pengelolaan limbah dan lainnya. Kawasan perkotaan memiliki persoalaan dengan keterbatasan lahan daratan untuk pengembangan infrastruktur kawasan kota, sehingga wilayah pesisir dianggap sebagai solusi yang mudah dan relatif murah. Hal ini berdampak kepada pembukaan besar-besaran kawasan pesisir pantai untuk direklamasi dengan tidak mengindahkan kepentingan ekologi dan lingkungan hidup.

Sejatinya melakukan reklamasi harus melihat dampak yang akan muncul, seperti dampak sosial, ekonomi, budaya dan lingkungan hidup. Beberapa dampak lingkungan hidup yang biasanya diperhatikan misalnya perubahan arus laut, ketidakseimbangan dan kehilangan ekosistem penting, kenaikan permukaan air (berhubungan dengan pasang surut), bahan timbunan, sedimentasi, perubahan hidrologi dan lainnya dampak lingkungan yang berpotensi muncul.

Sedangkan dampak sosial budaya biasanya adalah potensi pelanggaran norma-norma atau tata nilai (kearifan lokal) yang berlaku di suatu wilayah proyek reklamasi, pembebasan lahan, konflik masyarakat dengan pelaksana proyek reklamasi, perubahan kebudayaan, dan persoalaan sosial budaya lainnya. Untuk dampak secara ekonomi biasanya berada pada domain hilangnya mata pencaharian masyarakat (nelayan dan petambak) yang lahan miliknya direklamasi, dan aksesibilitas nelayan ke laut.

Kawasan tangkap dan budidaya sangat berperan penting dalam peningkatan asupan protein masyarakat dan peningkatan ekonomi masyarakat nelayan dan petambak, terutama yang berada pada wilayah perairan. Persoalaan yang sering muncul pada saat ini adalah semakin jauhnya nelayan tradisional menangkap ikan dan terdegradasinya lahan-lahan yang diperuntukkan sebagai lahan budidaya perikanan akibat pencemaran lingkungan dan alih fungsi kawasan. Hal ini ditambah dengan "over fishing" pada wilayah laut yang memiliki kepadatan wilayah tangkap. Seperti yang terjadi pada perairan laut kawasan barat Indonesia. Gejala over fishing ini berdampak kepada ekspansinya nelayan-nelayan dari kawasan perairan laut barat Indonesia ke kawasan perairan laut timur Indonesia. Mengingat kawasan perairan laut timur Indonesia belum mengalami over fishing dan pemanfaatan sumber daya ikan masih belum maksimal.

Dan jika pemerintah dan para pihak tidak memperhatikan hal tersebut dan memberikan solusi atas persoalaan ini, maka akan menimbulkan potensi konflik sesama nelayan yang disebabkan oleh perebutan akses/kawasan 
tangkap. Sementara sudah terjadi konflik antara nelayan tangkap dan di luar sektor perikanan seperti offshore (migas), penggunaan jalur transportasi laut, dan zona industri pada rencana zonasi.

Tingginya pencemaran lingkungan hidup dan perluasan daratan (reklamasi) pada wilayah pesisir, serta terdegradasinya hutan mangrove berpengaruh terhadap semakin susah dan jauhnya masyarakat nelayan menangkap ikan. Hal ini tentunya berdampak pada tingginya biaya operasional nelayan menangkap ikan, meningkatkan produksi tangkapan dan masih adanya pelaku usaha perikanan yang menggunakan alat tangkap yang tidak ramah lingkungan atau bahan-bahan yang berbahaya bagi keberlanjutan sumber daya perikanan, lingkungan dan manusia.

Sementara pada kawasan budidaya perikanan yang biasa dimanfaatkan, seperti areal pertambakan, keramba apung, bagang dan lainnya juga sangat bergantung kepada kondisi kelestarian ekosistem dan lingkungan hidup pada wilayah pesisir laut. Dengan terus terjaganya kondisi ekosistem dan lingkungan hidup, salah satunya akan berdampak pada peningkatan hasil produksi perikanan budidaya. Setidaknya jikapun tidak mengalami peningkatan, dapat menjaga stabilnya hasil produksi perikanan.

Dengan melihat dan mencermati beberapa contoh keterkaitan pemanfaatan wilayah pesisir laut di atas, maka sangat penting memperhatikan perencanaan peruntukan kawasan (zonasi) pada wilayah pesisir laut yang saling mengintegrasikan dengan peruntukan tata ruang daratan. Pengembangan wilayah pesisir menjadi salah satu tren pembangunan pada kawasan perkotaan, termasuk pengembangan Kawasan Strategis Nasional (KSN) dan Kawasan Strategis Provinsi (KSP).

\section{Rencana Tata Ruang Kawasan Strategis Provinsi KIO (Kawasan Industri Oleochemical) Maloy}

Dalam konteks lokal Kalimantan Timur, Rencana Tata Ruang (RTR) Kawasan Industri Oleochemical (KIO) Maloy di Kabupaten Kutai Timur dapat dijadikan sampel kasus bagaimana konektifitas berbagai elemen yang terdapat di wilayah pesisir dan daratan haruslah terintegrasi dan hendaknya tidak mengganggu kepentingan lingkungan hidup dan ekologi terutama yang berada di wilayah pesisir. KIO Maloy mengembangkan kawasannya menjadi zona industri, zona logistik dan zona pengolahan ekspor. Kawasan dengan luas sekitar +20.673 hektare ini terbagi menjadi Kawasan Inti 1 seluas + 1.000 hektare; Kawasan Inti 2 seluas + 4.673 hektare; dan Kawasan Penyangga seluas + 15.000 hektare. Dimana pada saat ini RTR KIO Maloy sedang dalam pembahasan oleh Pemerintah Daerah untuk kemudian ditetapkan dan disahkan menjadi Peraturan Daerah RTR KIO Maloy. Untuk lebih jelasnya dan mendapat gambaran mengenai RTR KIO Maloy, bisa dilihat gambaran peta rencana struktur ruang dan peta rencana pola ruang sebagai berikut :

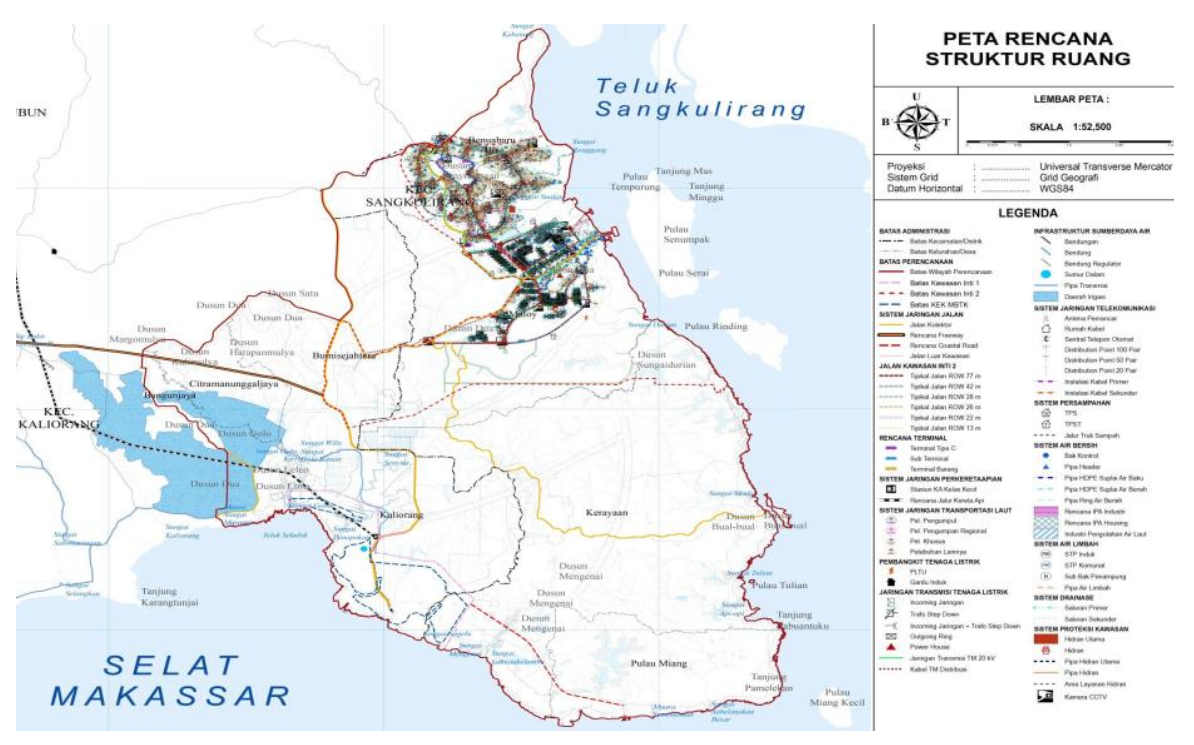

Gambar 1. Peta Rencana Struktur Ruang KIO Maloy (Sumber: Pemprov Kaltim) 


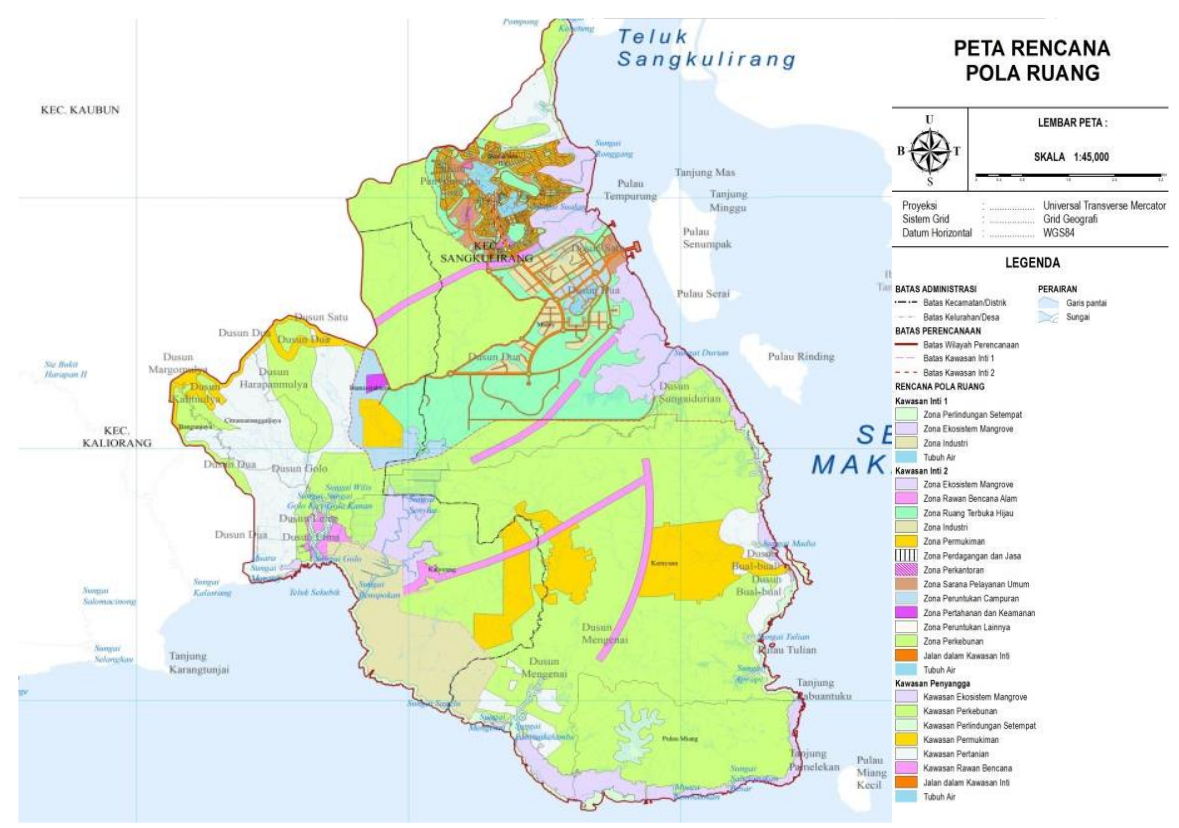

Gambar 2. Peta Rencana Pola Ruang KIO Maloy (Sumber: Pemprov Kaltim)

KIO Maloy atau yang dikenal dengan Kawasan Ekonomi Khusus (KEK) Maloy Batuta Trans Kalimantan menurut Peraturan Pemerintah (PP) No. 85 Tahun 2014 merupakan kawasan yang bersifat strategis untuk pengembangan perekonomian nasional dan daerah. Kawasan ini terletak pada lintasan Alur Laut Kepulauan Indonesia (ALKI II) yang merupakan lintasan laut perdagangan internasional dan masuk jalur interkoneksitas Kalimantan dan Sulawesi, yakni merupakan jalur regional lintas trans Kalimantan dan transportasi penyeberangan ferry Tarakan Tolitoli dan Balikpapan - Mamuju. Pemprov Kaltim juga telah mengeluarkan Peraturan Gubernur (Pergub) No. 4 Tahun 2018 Tentang Pendelegasian Kewenangan Pemberian Perizinan dan Non Perizinan Pemprov Kaltim Kepada Administrator Kawasan Ekonomi Khusus Maloy Batuta Trasn Kalimantan.

\section{Telaah Kritis RTR KIO Maloy}

Analisis kritis ini melihat dari sudut pandang keruangan dan mengintegrasikan Rencana Tata Ruang (RTR) KIO Maloy dengan Rencana Tata Ruang Wilayah Provinsi (RTRWP) Kalimantan Timur dan Rencana Zonasi Wilayah Pesisir dan Pulau-Pulau Kecil (RZWP3K), serta analisa dari penutupan lahan, kondisi existing dan dokumen lainnya yang bersumber dari pemerintah pusat dan daerah. Peta di bawah ini memuat mengenai perbandingan pola kawasan inti 1 dikomparasi dengan peta penutupan lahan Kementerian Lingkungan Hidup dan Kehutanan (KLHK) 2017 dan Citra Satelit Landsat 8, pada 4 Maret 2019 


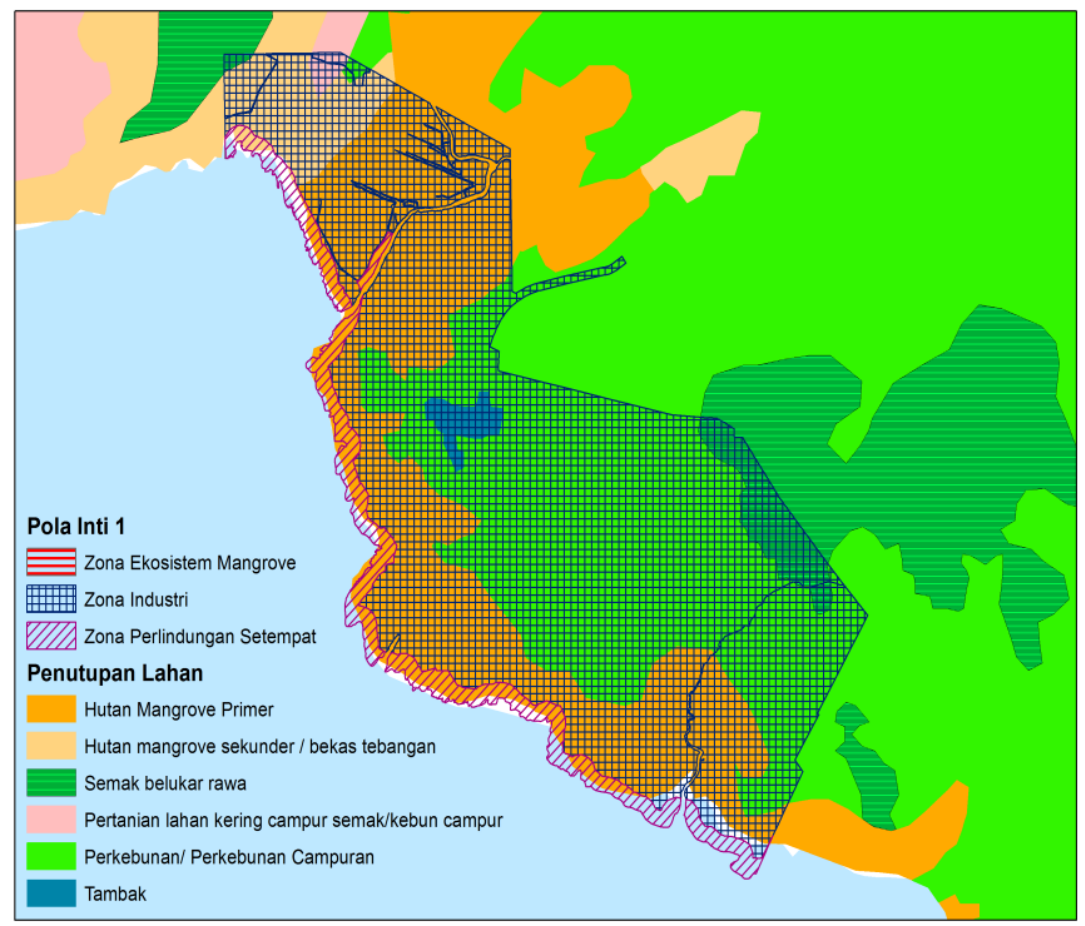

Gambar 3. Perbandingan Kawasan Inti 1 dengan Penutupan Lahan KLHK, Tahun 2017 (diolah)

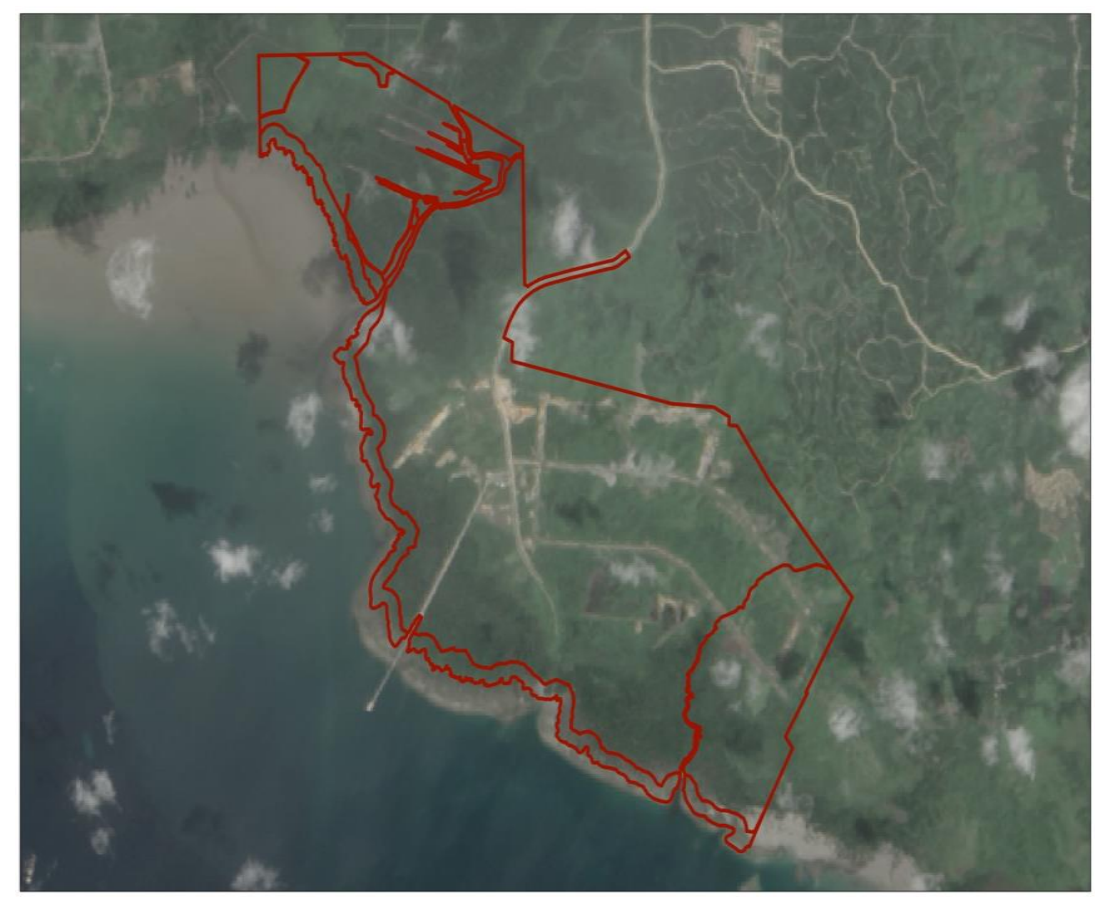

Gambar 4. Perbandingan Kawasan Inti 1 dengan Citra Landsat 8 (diolah)

Pada gambar 3 dan 4 tampak jelas bahwa keberadaan hutan mangrove primer terancam oleh perluasan dan pengembangan zona industri. Sementara pada RTR tersebut hanya menyisakan sedikit zona perlindungan setempat dan zona ekosistem mangrove. Dalam peta Citra Landsat 8 juga terlihat ketebalan ekosistem hutan mangrove primer yang terancam yang seharusnya dilindungi sebagai penyeimbang dan penjaga ekosistem pesisir. Dalam peta RTR (gambar 3 dan 4) tersebut hanya menetapkan zona perlindungan ekosistem hutan mangrove di sepanjang wilayah pesisir yang membujur dengan ketebalan yang relatif tipis, dan tentu 
ISSN (e) : 2527-564X / ISSN (p) 2621-0746

Website Journal : http://www.ejournal-academia.org/index.php/renaissance

saja tidak sesuai dengan kaidah Nilai Keanekaragaman Hayati Tinggi (NKHT).

Begitu juga halnya dengan kawasan inti 1, pada peta di bawah ini memuat mengenai perbandingan pola kawasan inti 2 yang

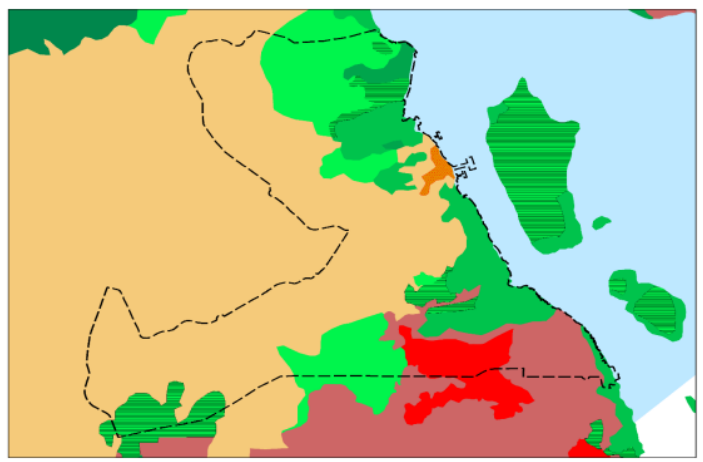

dikomparasi dengan peta penutupan lahan Kementerian Lingkungan Hidup dan Kehutanan (KLHK) 2017 dan Citra Satelit Sentinel 2 pada 4 Maret 2019.

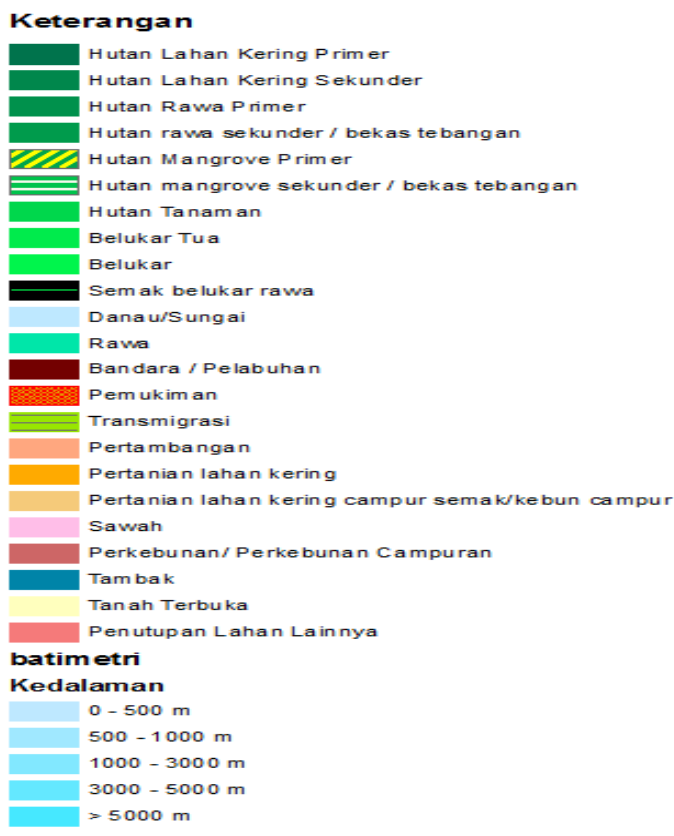

Gambar 5. Perbandingan Kawasan Inti 2 Tutupan Lahan KLHK, Tahun 2017 (diolah)

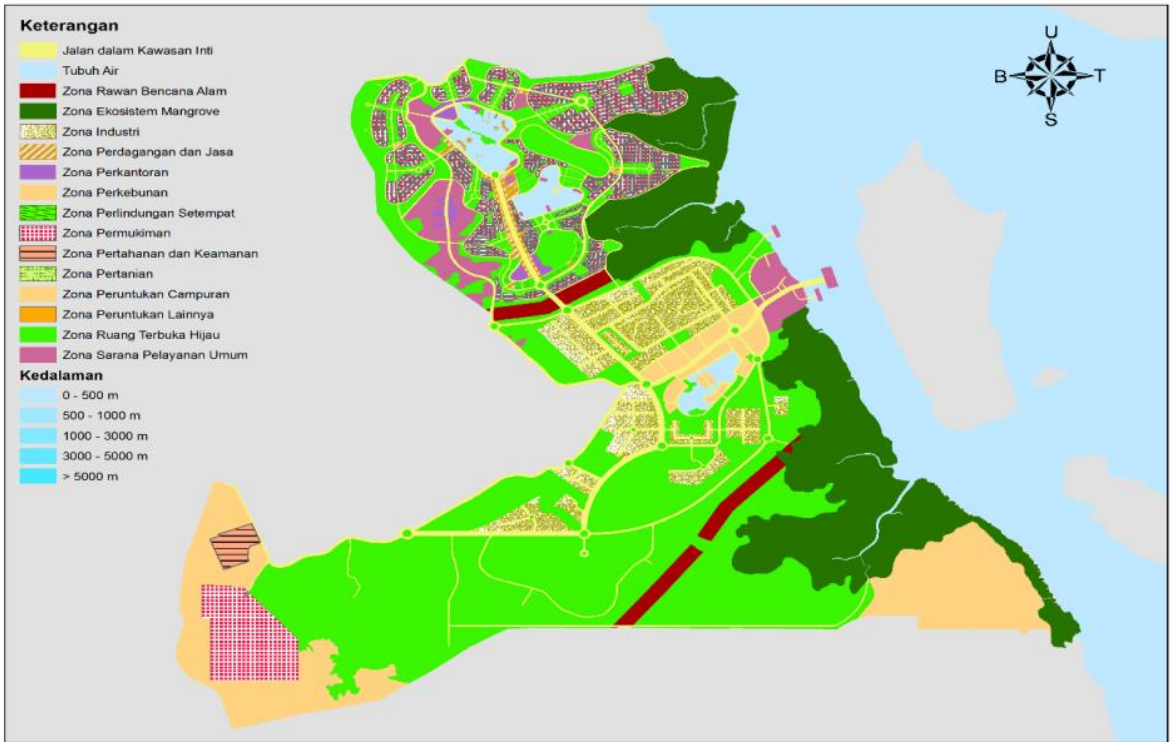

Gambar 6. Pemanfaatan Ruang Zona Inti 2 (diolah) 


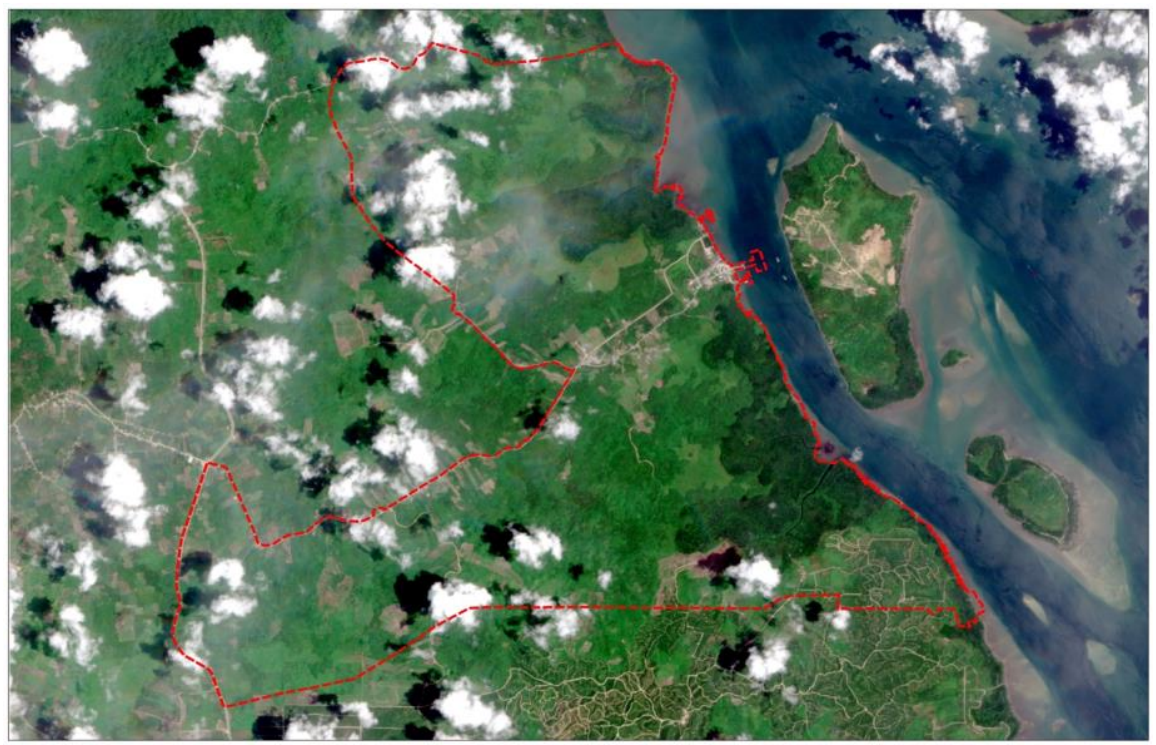

Gambar 7. Perbandingan Zona 2 Dengan Citra Satelite Sentinel 2 (diolah)

Terlihat pada Zona Inti 2 di wilayah pesisir (teluk) terdapat bukaan lahan yang terkategori pertanian lahan kering campuran dan perkebunan yang dikomparasi dengan masih terdapatnya ekosistem hutan lahan kering primer, hutan lahan kering sekunder, hutan arawa primer dan sekunder, hutan mangrove sekunder bekas tebangan dan sedikit hutan mangrove primer yang letaknya di belakang hutan mangrove sekunder. Zona pelayaran umum dalam pola pemanfaatan ruang juga terdapat pada wilayah pesisir (teluk) bersandingan dengan zona Ruang Terbuka Hijau (RTH) dan jalan dalam kawasan inti. Pada zona ini yang mengkhawatirkan adalah tingginya sedimentasi pada wilayah perairan teluk dimana akan berdampak pada pendangkalan dan susahnya kapal-kapal besar akan bersandar, serta tingginya tingkat abrasi di beberapa tempat sepanjang pinggiran pantai.

\section{KESIMPULAN}

Keberadaan hutan mangrove primer terancam oleh perluasan dan pengembangan zona industri. Sementara pada RTR tersebut hanya menyisakan sedikit zona perlindungan setempat dan zona ekosistem mangrove.

Zona pelayaran umum dalam pola pemanfaatan ruang juga terdapat pada wilayah pesisir (teluk) bersandingan dengan zona Ruang Terbuka Hijau (RTH) dan jalan dalam kawasan inti. Pada zona ini yang mengkhawatirkan adalah tingginya sedimentasi pada wilayah perairan teluk dimana akan berdampak pada pendangkalan dan susahnya kapal-kapal besar akan bersandar, serta tingginya tingkat abrasi di beberapa tempat sepanjang pinggiran pantai.

Sebaiknya RTR KIO Maloy harus dievaluasi dengan mempertimbangkan beberapa aspek. Pertama, RTR Maloy haruslah sesuai dengan Kajian Lingkungan Hidup Strategis (KHLS) dimana salah satu rekomendasinya adalah membiarkan ekosistem hutan mangrove primer untuk tidak diganggu gugat, dan hal ini sejalan dengan Peta Indikatif Penundaan Izin Baru (PIPIB) versi 15 yang dikeluarkan oleh Kementerian Lingkungan Hidup dan Kehutanan.

Kedua, RTR KIO Maloy haruslah disinergikan dengan Rencana Zonasi Wilayah Pengelolaan Pesisir dan Pulau-Pulau Kecil (RZWP3K), dimana RTR Maloy dibuat sebelum penetapan RZWP3K Provinsi Kaltim dan belum masuk dalam batang tubuh RZWP3K. Ketiga, merehabilitasi Kawasan pesisir (teluk) dimana sedimentasinya terlihat mengkhawatirkan. Keempat, melibatkan masyarakat luas yang berkepentingan dalam pembahasan RTR KIO Maloy.

Dengan melihat realita studi kasus dalam pengembangan wilayah pesisir, maka pengelolaan kawasan dan sumber daya pesisir perlu dilakukan secara hati-hati dan terintegrasi 
dengan mempertimbangkan penataan ruang daratan dan penataan zonasi. Hal ini dimaksudkan agar terwujudnya pengelolaan

\section{DAFTAR PUSTAKA}

BAPPENAS. (2016). Issue Strategis dan Permasalahan Sektor Perikanan Tangkap dan Budidaya.

Bengen, D.G. (2015). Presentasi Konsepsi Pengelolaan Wilayah Pesisir dan PulauPulau Kecil Terpadu. Himpunan Ahli Pengelola Pesisir Indonesia (HAPPI).

Bengen, D.G. (2015). Presentasi Perspektif Perencanaan Zonasi Wilayah Pesisir dan Pulau-Pulau Kecil. Himpunan Ahli Pengelola Pesisir Indonesia (HAPPI).

Damanik, R. Suhana. Prasetiamartati, B. (2008). Menjala Ikan Terakhir, Sebuah Fakta Krisis Di Laut Indonesia. Wahana Lingkungan Hidup Indonesia (WALHI).

Damanik, R. (2014). Menggerakkan Poros Maritim. Indonesia For Global Justice dan Kesatuan Nelayan Tradisional Indonesia.

Idrus, V. (2013). Reklamasi Pantai Dalam Kumpulan Jurnal. Academia.Edu

Kaltim, Pemprov. (2018). Naskah Akademik Rencana Tata Ruang Kawasan Strategis Provinsi (KSP) KIO Maloy. Dinas Pekerjaan Umum Penataan Ruang dan Perumahan Rakyat.

Kaltim, Pemprov. (2018). Draft Akhir Raperda Rencana Tata Ruang KSP KIO Maloy. Dinas Pekerjaan Umum Penataan Ruang dan Perumahan Rakyat.

Kaltim, Pemprov. (2018). Kajian Lingkungan Hidup Strategis (KLHS) RTR KIO Maloy. Dinas Pekerjaan Umum Penataan Ruang dan Perumahan Rakyat.

Muhajir, Noeng. (1996). Metodologi Penelitian Kualitatif. Yogyakarta: Rake Sarasin.

Nur Indar, Y. (2015). Presentasi Sosial, Ekonomi dan Budaya Masyarakat Pesisir dan Pulau-Pulau Kecil. Himpunan Ahli Pengelola Pesisir Indonesia (HAPPI).I wilayah pesisir yang lestari dan dapat dirasakan oleh generasi selanjutnya.

Official, KLHK. (2017). Peta Tutupan Hutan dan Lahan. Kementerian Lingkungan Hidup dan Kehutanan Republik Indonesia.

Peraturan Pemerintah Nomor 85 Tahun 2014 Tentang Kawasan Ekonomi Khusus Maloy Batuta Trans Kalimantan

Peraturan Gubernur Kalimantan Timur Nomor 4 Tahun 2018 Tentang Pendelegasian Kewenangan Pemberian Perizinan dan Non Perizinan Pemerintah Provinsi Kalimantan Timur Kepada Administrator Kawasan Ekonomi Khusus Maloy Batuta Trans Kalimantan

Proyek Pesisir. (2004). Pengelolaan Wilayah Pesisir Terpadu. Rencana Strategis Pengelolaan Terpadu Teluk Balikpapan. Koleksi Dokumen Proyek Pesisir Tahun 1997 - 2003. USAID. Indonesia Coastal Resources Management Project.

Rudianto, Eko. (2015). Presentasi Implementasi Pemanfaatan Wilayah Pesisir Terpadu. Direktorat Jenderal Kelautan, Pesisir dan Pulau-Pulau Kecil. Kementerian Kelautan dan Perikanan.

Rudianto, Eko. (2015). Presentasi Kebijakan Pembangunan Kelautan, Pesisir dan PulauPulau Kecil Indonesia. Direktorat Jenderal Kelautan, Pesisir dan Pulau-Pulau Kecil. Kementerian Kelautan dan Perikanan.

Sugiyono. (2012). Metode Penelitian Kuantitatif, Kualitatif, dan Kombinasi (Mixed Methods). Alfabeta, Bandung,

Undang-Undang Republik Indonesia Nomor 26 Tahun 2007 Tentang Penataan Ruang.

Undang-Undang Republik Indonesia Nomor 27 Tahun 2007 Tentang Pengelolaan Wilayah Pesisir dan Pulau-Pulau Kecil.

Undang-Undang Republik Indonesia Nomor 1 Tahun 2014 Tentang Perubahan Atas Undang-Undang Nomor 27 Tahun 2007 Tentang Pengelolaan Wilayah Pesisir dan Pulau-Pulau Kecil. 